\title{
Could the severity of COVID-19 be increased by low gastric acidity?
}

\author{
Elizabeth Price
}

Could low gastric acidity increase the risk of a severe COVID-19 illness? Although it is primarily a respiratory infection, gastrointestinal involvement from swallowed coronaviruses is reported for SARS-CoV-2 (the virus of COVID-19 [1, 2]), as well as SARS-CoV-1 [3] and MERS-CoV viruses [4].

The gastrointestinal tract may be a secondary route for spread to the lungs and other parts of the body. A possible hypothesis might be that the upper respiratory tract is attacked by viruses which are breathed in and coughed up in sputum while the lower respiratory tract is similarly infected, but is also attacked at the same time by bloodborne viruses (following translocation from a significant viral load in the gastrointestinal tract). The former might result in mild or moderate illnesses only. The latter may cause a more severe illness, as the lungs are being attacked by viruses coming from two routes simultaneously.

Although it can be transiently higher, the $\mathrm{pH}$ of normal gastric acid is generally between 1.5 and 3.5. The SARS-CoV-1 virus is inactivated at a $\mathrm{pH}<3.0$ and $>12.0$ [5]. Assuming these inactivation levels are similar for SARS-CoV-2, gastric acid will not inhibit all the viruses in the stomach (and some viruses will be hidden in food boluses). However, the inhibition that does occur may be enough to decrease the viral load entering the small intestine. In many older adults, the gastric acid $\mathrm{pH}$ is higher than normal, either because of atrophic gastritis or because of antacid and acid-reducing medications. One oral dose of a proton pump inhibitor raises the gastric acid $\mathrm{pH}$ from 2.0 to over 6.0 , which will not inhibit the virus [6]. (For MERS-CoV, treatment with a proton pump inhibitor in an animal model resulted in exaggerated infection in the small intestine [4].)

Correspondence: elizabethshanson@btinternet.com London, UK

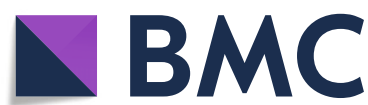

(c) The Author(s). 2020 Open Access This article is licensed under a Creative Commons Attribution 4.0 International License, which permits use, sharing, adaptation, distribution and reproduction in any medium or format, as long as you give appropriate credit to the original author(s) and the source, provide a link to the Creative Commons licence, and indicate if changes were made. The images or other third party material in this article are included in the article's Creative Commons licence, unless indicated otherwise in a credit line to the material. If material is not included in the article's Creative Commons licence and your intended use is not permitted by statutory regulation or exceeds the permitted use, you will need to obtain permission directly from the copyright holder. To view a copy of this licence, visit http://creativecommons.org/licenses/by/4.0/ The Creative Commons Public Domain Dedication waiver (http://creativecommons.org/publicdomain/zero/1.0/) applies to the data made available in this article, unless otherwise stated in a credit line to the data. 


\section{Acknowledgements}

I acknowledge the advice of the following:

Dr. David Treacher MA FRCP

Dr. Gee Yen Shin MSC MRCP FRCPath

Professor John Walker-Smith MD FRCP FRACP FRCHCH

\section{Author's contributions}

See above. I am the sole author. The author read and approved the final manuscript.

\section{Funding}

No funding is involved.

\section{Availability of data and materials}

Not applicable

\section{Ethics approval and consent to participate}

No ethical approval or consent to participate was involved.

\section{Consent for publication}

I am the sole author and I consent to publication. The material is original, unpublished and is not submitted elsewhere.

\section{Competing interests}

There was no conflict of interest.

Received: 1 July 2020 Accepted: 15 July 2020

Published online: 22 July 2020

\section{References}

1. Yang L, Tu L. Implications of gastrointestinal manifestations of COVID-19. Lancet Gastroenterol Hepatol 2020 Published Online May 12, 2020 https:// doi.org/10.1016/S2468-1253(20)30132-1.

2. Henry BM, de Oliveira MHS, Benoit J, Lippi G. Gastrointestinal symptoms associated with severity of coronavirus disease 2019 (COVID-19): a pooled analysis. Intern Emerg Med. 2020. https://doi.org/10.1007/s11739-020-02329-9.

3. Shi X, Gong E, Gao D, Zhang B, Zheng J, Gao Z, et al. Severe acute respiratory syndrome associated coronavirus is detected in intestinal tissues of fatal cases. Am J Gastroenterol. 2005;100(1):169-76.

4. Zhou J, Li C, Zhao G, Chu H, Wang D, Yan HH, et al. Human intestinal tract serves as an alternative infection route for Middle East respiratory syndrome coronavirus. Sci Adv. 2017;3(11):eaao4966. https://doi.org/10.1126/sciadv. aao4966.

5. Darnell MER, Subbarao K, Feinstone SM, Taylor DR. Inactivation of the coronavirus that induces severe acute respiratory syndrome, SARS-Co-1. J Virol Methods. 2004;121(1):85-91.

6. Freedberg DE, Lebwohl B, Abrams JA. The impact of proton pump inhibitors on the human gastrointestinal microbiome. Clin Lab Med. 2014; 34(4):771-85. https://doi.org/10.1016/j.cll.2014.08.008.

\section{Publisher's Note}

Springer Nature remains neutral with regard to jurisdictional claims in published maps and institutional affiliations. 